\title{
A Retained Wood Penetrating the Superior Orbital Fissure in a Neurologically Intact Child
}

\author{
Nörolojik Intakt Çocukta Superior Orbital Fissürü Penetre Eden Ağaç \\ Parçast
}

Ahmet Metin SANLI, Hayri KERTMEN, Erdal Resit YILMAZ, Zeki SEKERCİ

M.H. Diskapi Yildirim Beyazit Education and Research Hospital, Department of First Brain Surgery, Ankara, Turkey

Correspondence address: Ahmet Metin SANLI / E-mail: ahmetmetinsanli@hotmail.com

\begin{abstract}
Transorbital intracranial injuries due to a wooden foreign body traversing superior orbital fissure is an extremely rare condition. A 9-year-old boy was struck by a tree branch in the left eye while playing in the garden two months ago. On physical examination, the patient had only a hypertrophic scar on his medial side of left upper eyelid at the admission. A history of recurrent cutaneous fistula from the puncture site due to a retained foreign body was suspected, and the patient was hospitalized to evaluate and remove the object to prevent severe infection. Afterwards, the child was operated successfully via the left transcranial route to detect and remove the foreign body. The authors described an unusual case of wooden foreign body that traversed the superior orbital fissure yet caused no deficit and was associated with no fracture. Even if symptoms are absent, removal of a wooden foreign body should be immediately performed to prevent sight-threatening and lifethreatening complications.
\end{abstract}

KEYWORDS: Orbitocranial, Superior orbital fissure, Wooden, Foreign body

öz

Superior orbital fissürü kateden ağaç yabancı cismin neden olduğu transorbitokranial yaralanmalar oldukça nadirdir. Dokuz yaşında erkek çocuk bahçede oynarken, ağaç parçası sol gözüne batmıştır. Başvuru sırasında fizik muayenede yalnızca sol üst göz kapağı medial kısmında hipertrofik skar bulunmuştur. Yaralanma noktasından tekrarlayan fistülün bir yabancı cisim şüphesine neden olmasıyla, incelemek ve şiddetli bir enfeksiyonu önlemek amacıyla çıkartmak üzere hastaneye yatırılmıştır. Ardından, saptanan yabancı cismi çıkartmak için transkranial yol kullanılarak başarı ile opere edilmiştir. Yazarlar, superior orbital fissürü katederek defisite ve kırığa neden olmayan nadir bir tahta yabancı cisim olgusu tanımlamıştır. Semptom olmasa bile tahta yabacı cismin çıkarılması, görmeyi ve hayatı tehdit eden komplikasyonları önlemek için hemen gerçekleştirilmelidir.

ANAHTAR SÖZCÜKLER: Orbitokranial, Superior orbital fissür, Tahta, Yabancı cisim

\section{INTRODUCTION}

Transorbital intracranial penetrating injuries due to wooden foreign bodies and especially those not fracturing any of the walls of the orbit and going through the superior orbital fissure are extremely rare $(1-3,6,8,9)$. In the present report, authors described an unusual case of the transorbital intracranial penetrating injury, which appears to be first such case in the literature. Even if a patient appears neurologically intact, a history of draining fistula at a puncture site may be helpful to neurosurgeons to prevent disastrous intracranial complications of a retained wooden foreign body.

\section{CASE REPORT}

A 9-year old boy was struck by a tree branch in the left eye while playing in the garden two months ago. The patient was immediately brought to a physician at a local hospital. On first physical examination, no abnormalities of the eyeballs or eye movement and no neurological abnormalities were observed. A minor superficial wound was seen in his left upper eyelid, but did not need suturing. No fracture or foreign body was found on plain x-ray examination, and the patient went home after given tetanus toxoid injection. The patient visited a local ophthalmologist one month later because of a draining fistula on his left upper eyelid. The patient was neurologically intact and culture results were negative, and the patient was managed with oral flucloxacillin and chloromycetin ointment in a preventative manner. Two weeks later, the fistula was completely closed and a minor periorbital erythema was seen at the puncture site on the control examination. The patient was referred to a neurosurgery department two weeks later because of a recurrence of previously resolved fistula. On the third physical examination, external examination of the left eye revealed no purulent discharge or fistula and a hypertrophic scar of the puncture site was present just superior to the medial canthus of the left eye (Figure $1 \mathrm{~A}$ ). The left eye also demonstrated a mild upper eyelid edema. The remainder of the neurological and ophthalmological examination showed no abnormalities.A history of recurrent cutaneous fistula from 


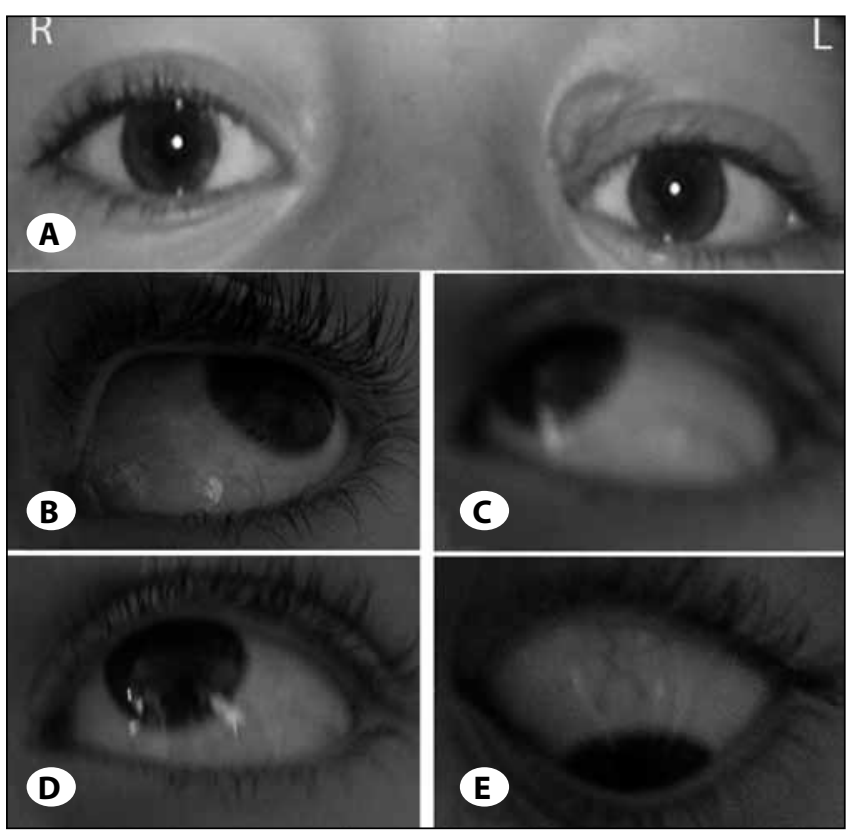

Figure 1: Photograph of both eyes showing the site of penetration of the left upper eyelid and left ocular movement. Both eyes are in normal position at horizontal gaze and a the hypertrophic scar of entry site was noted at upper eyelid. The left eye also demonstrated a mild upper eyelid edema ( $\mathbf{A}$, before surgery). There was no evidence of global ophthalmoplegia of the left eye: abduction (B), adduction (C), upward (D) and downward gaze (E) were full (after surgery). There was also total resolution of the hypertrophic scar at the entry site.

a foreign body puncture site was suspected and the patient was immediately hospitalized to evaluate and remove the foreign body to prevent severe infection

On further neuroradiological investigations, a $10 \times 25 \mathrm{~mm}$ rodshaped intracranial structure, lying along the medial aspect of the left orbit and passing through the superior orbital fissure and into the left cavernous sinus was seen in MRI on admisson. T1 WI and T2WI MRI showed high and markedly low signals of the foreign body, respectively (Figure 2A,B). In addition, Gdenhanced MRI showed a ring-enhanced lesion surrounding the structure (Figure 2C-F). Such anatomical relationship were confirmed by CT demonstrating the foreign body lateral to the left internal carotid artery. CT scan demonstrated well demarcated, linear hyperdense structure measuring $10 \times 25 \mathrm{~mm}$ (Figure 3A). After identification of the retained foreign body, surgical exploration was planned. The patient underwent a left pterional craniotomy and the posterior orbit was unroofed to permit removal of the foreign body. At this point, the left orbit was exposed, but the expected foreign body was not found. The dissection was continued inferiorly with removal of the medial orbit wall. A wooden foreign body lying in the surrounding pseudomembranes was identified between the medial rectus and the inferior wall of the left orbit. After opening the membranes, a minimal abscess was drained, the wooden foreign body was seen and it was then carefully removed. After resection of the foreign body, no hemorrhage occurred along its track and no fragmentation of the foreign body was seen (Figure 3B-C).

In the immediate postoperative period, the patient was neurologically intact. His postoperative course was uneventful, and he was discharged one week later. One years later, the neurological and ophthalmological examination showed no abnormalities (Figure 1B-D).

\section{DISCUSSION}

Wooden foreign bodies that penetrate through the orbit such as periorbital penetration are not uncommon in children $(1,2,6,8)$, whereas transorbital intracranial injuries due to wooden foreign bodies via the natural openings of orbit are rare conditions. The orbit is in the shape of a horizontal pyramid on a posteromedial axis and forms an easy path for low velocity foreign bodies into the intracranial space $(2,7,10)$. This shape tends to deflect objects entering the orbit toward the apex where the superior orbital fissure and optic foramen may provide a passage to the intracranial contents $(2,10)$. Transorbital intracranial penetrating injuries due to wooden foreign bodies are extremely rare, especially those going through the superior orbital fissure (9).

Clinically, a major neurological symptom may be absent on first examination in children in particular when the penetration is not via the superior orbital fissure or optic canal and the eyeball is not injured (7). On neurological examination, ophthalmopathy and neurological abnormalities are absent immediately after injury unless the lesion is complicated by many types of intracranial haematomas $(2,6)$. These are most common characteristics of the periorbital penetrations in common clinical practice. On the other hand, if the wood passes through the intracranial cavity via the superior orbital fissure, it may cause trauma to the 3th, 4th, 5th and 6th cranial nerves or produce a traumatic arterial fistula involving the carotid artery and cavernous sinus $(3,8,9)$. These findings in children can be supported by case reports in relevant literature (Table I). The most common characteristics of five cases on initial neurological examinations were accompanied by serious cranial nerve palsies $(2,3,5,7,10)$. Only an asymptomatic case was immediately operated after penetrating transorbital intracranial injury(4), whereas in the present case, the patient is only a child who is neurologically intact despite a delayed admission. Possible mechanisms of intact neurological examination may be explained for using antimicrobial therapy and draining of the orbital infection via cutaneous fistula at the puncture site.

If a wooden object enters the cranial cavity via the natural openings, diagnosis can be very difficult(6). Description of an orbitocranial wooden foreign body may not be easy to find initially. Firstly, detection of wooden foreign bodies and small fractures based on plain x-ray examination is difficult. Secondly, CT is ideal for evaluating fractures of the orbital walls and the integrity of adjacent sinuses and has little value in detecting wooden foreign bodies penetrating via the superior orbital fissure or optic canal and dry wood alone $(3,7)$. In addition, the CT appearances seem related to 

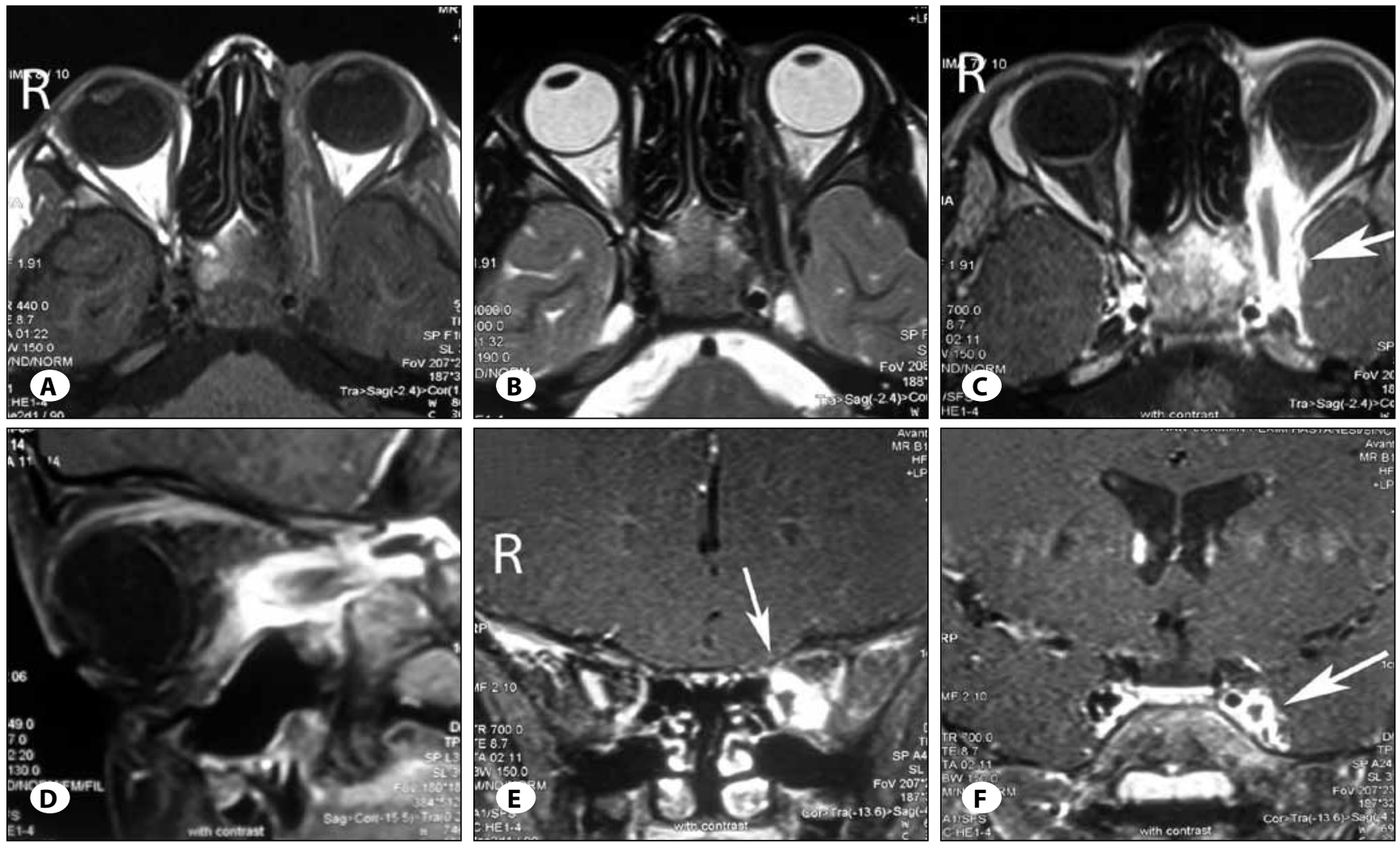

Figure 2: Magnetic resonance imaging of the head. MRI showed a brain-hyperintense signal in T1-W (A), but hypointense in T2-W (B). After adding gadolinium DTPA, the same structure with contrast enhancement in rim was clearly visible. [(C) axial; (D) parasagittal] White arrows point to a rod-shaped structure inferomedial to the left orbit (E) that extends into the left cavernous sinus and just lateral to the left internal carotid artery (F).

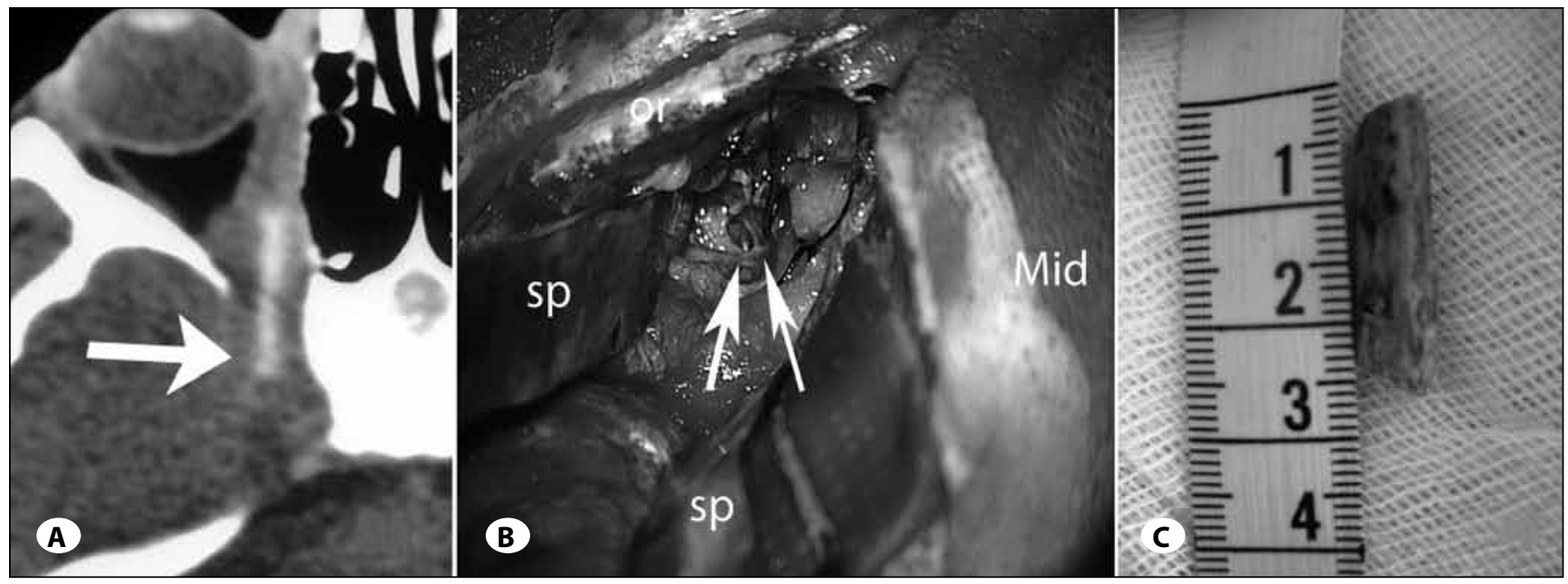

Figure 3: Left orbital CT and photographs of the surgical field and wooden foreign body. The white arrow points to a hyperdense linear structure in the left orbit extending through the superior orbital fissure and into the left cavernous sinus (A). The white arrows point to a cavity and retained pseudomembranes in left orbit. No hemorrhage occurred along its track and no fragmentation of the foreign body was seen (B) (mid: midline, orb: orbit, spt: spatula). A 10x25 mm wooden foreign body was removed in surgery (C).

the interval between injury and examination. Wooden sticks may incite an inflammatory reaction and become walled off in the soft tissues, and can be difficult to localize $(1,9)$. MRI has advantages over CT for imaging the foreign body when a non-metal foreign body such as wooden objects is suspected.
A wooden foreign body is imaged as a low-signal material during the early stage after injury and is differentiated from the surrounding air and fat tissues. Gd-enhancement MRI shows clearer images of the tissue around the foreign body and is also useful for the diagnosis (7). 
Table I: Summary of Reported Cases of Wooden Foreign Body which Traversed the Superior Orbital Fissure was Associated with no Fracture in Children

\begin{tabular}{|c|c|c|c|c|}
\hline Author-Year & $\begin{array}{l}\text { Age- } \\
\text { Gender }\end{array}$ & $\begin{array}{l}\text { Penetration } \\
\text { Site and Initial } \\
\text { Presentation }\end{array}$ & Intracranial Complication & $\begin{array}{l}\text { Interval to } \\
\text { intracranial } \\
\text { complication }\end{array}$ \\
\hline Hansen et al. (1988) (2) & $7 y, M$ & $\begin{array}{l}\text { Lower eyelid } \\
\text { penetration, } \\
\text { Ophthalmoplegia }\end{array}$ & Carotid Sinus Trombosis & $\begin{array}{l}\text { Surgery } \\
\text { immediately }\end{array}$ \\
\hline Zentner et al. (1991) (10) & $12 y, M$ & $\begin{array}{l}\text { Lower eyelid } \\
\text { penetration, } \\
\text { Amaurosis, } \\
\text { Ophthalmoplegia }\end{array}$ & Orbital abscess & $4 d$ \\
\hline Kahler et al. (1998) (3) & $15 \mathrm{~m}, \mathrm{M}$ & $\begin{array}{l}\text { Lower eyelid } \\
\text { penetration, } \\
\text { Ptosis, VI } \\
\text { (Abducens Nevre) } \\
\text { palsy, CSF fistula }\end{array}$ & $\begin{array}{l}\text { Carotid Sinus Trombosis, Penetration of } \\
\text { prepontine cistern, Meningism }\end{array}$ & $4 d$ \\
\hline Smely et al. (1999) (7) & $2 \mathrm{y}, ?$ & $\begin{array}{l}\text { Lower eyelid } \\
\text { penetration, } \\
\text { Ptosis, Mydriasis }\end{array}$ & $\begin{array}{l}\text { Penetration of parapontine cistern, } \\
\text { Exophthalmos (retrobulber collection of CSF) }\end{array}$ & $10 \mathrm{~d}$ \\
\hline Matsuyama et al. (2001) (4) & $1 y, M$ & $\begin{array}{l}\text { Upper eyelid } \\
\text { penetration }\end{array}$ & $\begin{array}{l}\text { Penetration of prepontine cistern, Orbital } \\
\text { abscess }\end{array}$ & $\begin{array}{l}\text { Surgery } \\
\text { immediately }\end{array}$ \\
\hline Mitilian et al. (2009) (5) & $4 y, M$ & $\begin{array}{l}\text { Lower eyelid } \\
\text { penetration, } \\
\text { Mydriasis, } \\
\text { Hemiparesis }\end{array}$ & Penetration of prepontine cistern & $24 \mathrm{~h}$ \\
\hline Present (2010) & $9 y, M$ & $\begin{array}{l}\text { Upper eyelid } \\
\text { penetration }\end{array}$ & Orbital abscess & $2 \mathrm{~m}$ \\
\hline
\end{tabular}

$\boldsymbol{M}$, male; $\boldsymbol{F}$, female; $\boldsymbol{h}$, hour; $\boldsymbol{d}$, day; $\boldsymbol{m}$, month; $\mathbf{C S F}$, cerebro spinal fluid.

Serious complications of a retained piece of wood may occur days, months or even years after initial trauma $(1,9)$. In particular, the presence of a discharging sinus should evoke suspicion of a retained wooden object, regardless of the time interval between the trauma and current presentation $(3,6)$. In the reported case, a history of recurrent orbital cutaneous fistula caused a high clinical suspicion of retained foreign body. As a result of this suspicion, the child was hospitalized to evaluate and operate to prevent serious intracranial infection in the future.

In conclusion, the authors describe a highly unusual penetrating injury of the orbit in a child. Even if a patient with periorbital penetration appears physically stable, a minor delayed presentation, such as a resolved fistula at the puncture site, should increase clinical suspicion for orbitocranial penetration. A retained wooden foreign body must be removed even in absence of symptoms.

\section{REFERENCES}

1. Boncoeur-Martel MP, Adenis JP, Rulfi JY, Robert PY, Dupuy JP, Maubon A: CT appearances of chronically retained wooden intraorbital foreign bodies. Neuroradiology 43:165-168, 2001

2. Hansen JE, Gudeman SK, Holgate RC, Saunders RA: Penetrating intracranial wood wounds: Clinical limitations of computarized tomography. J Neurosurg 68:752-756, 1988

3. Kahler RJ, Tomlinson FH, Eisen DP, Masel JP: Orbitocranial penetration by a fern: Case report. Neurosurg 42:1370-1373, 1998

4. Matsuyama T, Okuchi K, Nogami K, Hata M, Murao Y: Transorbital penetreting injury by a chopstick. Neurol Med Chir (Tokyo) 41:345-348, 2001

5. Mitilian D, Charon B, Brunelle F, Di Rocco F: Removal of a chopstick out of the cavernous sinus, pons, and cerebellar vermis through the superior orbital fissure. Acta Neurochir (Wien) 151(10):1295-1297, 2009

6. Nishio $Y$, Hayashi N, Hamada H, Hirashima $Y$, Endo S: A case of delayed brain abscess due to a retained intracranial wooden foreign body: A case report and rewiev of the last 20 years. Acta Neurochir (Wien) 146:847-850, 2004 
7. Smely $\mathrm{C}$, Orszagh $\mathrm{M}$ : Intracranial transorbital injury by a wooden foreign body: Re-evulation of CT and MRI findings. Br J Neurosurg 13:206-211, 1999

8. Turbin RE, Maxwell DN, Langer PD, Frohman LP, Hubbi B, Wolansky L, Mori M: Patterns of transorbital intracranial injury: A review and comparison of occult and non-occult cases. Surv Ophtalmol 51(5): 449-460, 2006
9. Uchino A, Kato A, Takase Y, Kudo S: Intraorbital wooden and bamboo foreign bodies: CT. Neuroradiology 39:213-215, 1997

10. Zentner J, Hassler W, Petersen D: A wooden foreign body penetrating the superior orbital fissure. Neurochirurgia (Stuttg) 34:188-190, 1991 